\title{
Job placement for graduates as staff training criteria for construction industry at the current stage (by the case Immanuel Kant Baltic Federal University)
}

\author{
Lidiia Shershova ${ }^{1, *}$, Irina Nuzhina ${ }^{2,3}$, and Evgeny Kurochkin ${ }^{1}$ \\ ${ }^{1}$ Immanuel Kant Baltic Federal University (IKBFU), 14 A. Nevskogo str., Kaliningrad, 236016, \\ Russia \\ ${ }^{2}$ Tomsk State University of Architecture and Building, Solyanaya sg., 2, Tomsk, 634003, Russia \\ ${ }^{3}$ Tomsk State University of Control Systems and Radioelectronics, Lenina Prospect, 40, Tomsk, \\ 634050, Russia
}

\begin{abstract}
The aim of the survey is to study the employment of graduates of the direction «Construction» IKBFU for the period 2017-2018. The methods of systematic, logical and comparative analysis, the results of the public opinion survey on the employment of the «Construction» direction graduates, the results of the authors 'own research on identifying employers' preferences and the needs of the construction industry in the region, taking into account the development of new technologies in construction, were used. The aspects are shown and the content of the curricula determining the priorities in the training of personnel for the construction industry in the region is disclosed. The indexes of employment of graduates analysed as a criterion of the effectiveness of the activity of an educational institution. It is shown that practical orientation is an integral part of bachelors training, which is a special feature of the personnel training for the construction industry in the Kaliningrad region. The results of graduates employment monitoring are published. Priority profiles of personnel training for the construction industry in the region have been underlined. A comparative analysis could become an important area of results application for fine tuning of territorial labour and employment policy techniques.
\end{abstract}

\section{Introduction}

Training of professionals who are competitive both on the Russian and international labor market is one of the tasks of the Immanuel Kant Baltic Federal University (IKBFU) [1]. Currently, one of the areas of training in the I. Kant BFU for the region is training qualified personnel in the direction of "Construction». Today the construction industry is one in which the quality of training of specialists is directly visible. The construction complex,

\footnotetext{
*Corresponding author: shershovar@mail.ru
} 
which forms $5.5 \%$ of the gross domestic product and provides employment for about 3 million people, has retained its position as an important, socially beneficial and systemforming sphere of the Russian economy. The necessary volume of housing can be introduced only with the appropriate quantitative and, first of all, quality provision of the construction industry with human resources. Vladimir Yakovlev, the president of Russian Union of Builders, notes that at present there is practically no complete system of continuous professional building education in Russia, and as a result, not all is successful with the innovation, labor productivity of the domestic construction sector, especially in comparison with technologically advanced countries [2].

\section{Literature Review}

Studies of the graduates' employment problems are interdisciplinary in nature and include research on economics, sociology, construction management, construction industry development and training. Many scientists have been active in graduates employment data, among them the works of Garkin I.N., Medvedeva L.M. (2016), which reveal the peculiarities of adaptation of young specialists in the labor market [3]. One of the aspects of employment in the specialty of these authors is given to industrial practices as a guarantee of successful future employment $(2017,2016)[4,5]$. Employment of graduates through the career fairs is considered in the work of Boldyrev S.A., Medvedeva L.M. (2016) [6]. The problem of shortage skilled construction professionals in case of the Penza region is considered in the work of Zhukov A.N., Artyukhina O. V. (2014) [7]. At the same time in the work of Agafonova E.A. «The employment of graduates as one of the indicators of the effectiveness of the university at the present stage: analysis, problems and prospects», the author emphasizes the significance of innovation and focuses on the creation of objective criteria for assessing this parameter for the university (2014) [8].

At the same time, there are not enough studies that focused on the problems of interlinks between the educational process and employment, including the use of mechanism of integration construction business representatives into educational process.

\section{Materials and methods}

In recent years, Russian educational standards for personnel training are in a process of strong improvement, including the Federal State Educational Standard for Higher Education in the field of training 08.03.01 «Construction» (bachelor's level) (2015) [9].

Within the framework of the educational standard, the structure of the bachelor's training program includes the basic and variable parts. The basic part is compulsory for all state educational institutions of the country, but the variable part was left to the discretion of the university. This provides an opportunity to implement bachelor's programs with taking into account the current trends in regional labor market.

In addition, in accordance with this standard, the share of employees (in terms of integer salary scales) among managers and employees of organizations whose activities are related to the direction (profile) of the bachelor's program being implemented should be at least $5 \%$ [9].

Currently, the Immanuel Kant Baltic Federal University on stream of study «Construction» provides training for several levels, including programs of secondary vocational training, bachelor's and master's degrees. The undergraduate program in the field of «Industrial and civil construction» is carried out by full-time and part-time forms of training. The Master's program «Modern technologies for designing and calculating building structures» is conducted by correspondence course. 
It should be noted that as of 2018, both training programs (Bachelor's, Master's) in the direction of «Construction» have state accreditation.

There were first graduation by students of first degree profile «Industrial and civil construction» from the direction of «Construction» in 2017-2018.

Employment of graduates of an educational establishment of higher professional education in the specialty within three years after graduation is one of the target indicators of the university's effectiveness criteria [10].

Monitoring employment of IKBFU graduates of the direction «Construction» for 20172018 showed that all graduates in the amount of $100 \%$ were employed [Fig. 1].

This was the first graduate degree in the direction, which numbered 25 persons.

\section{Employment of graduates of all forms of study, direction "Construction"in 2017-2018 years.}

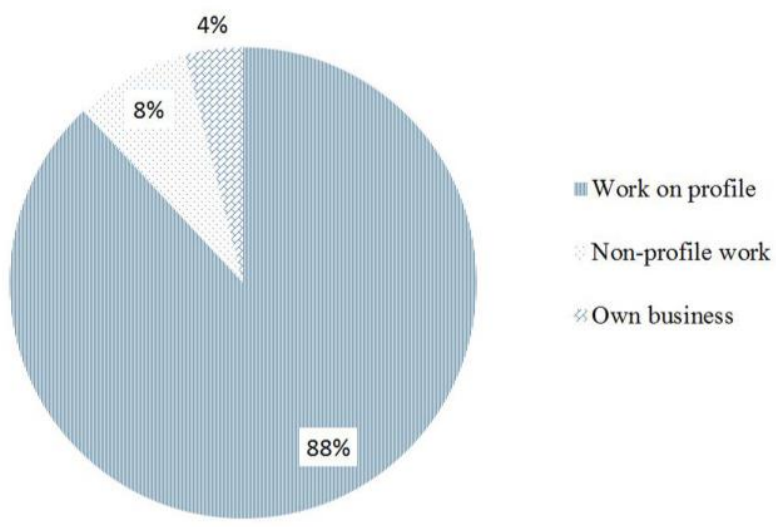

Fig. 1. Caption Diagram of employment of graduates of the direction «Construction», the profile «Industrial and civil construction» IKBFU in 2017-2018, full-time and part-time forms of study.

Irrespective of the type of instruction, the percentage of graduates who aren't employed in accordance with profile of training is less than $10 \%$, which is one of the prerequisites for efficiency of the institution [Fig. 2, Fig. 3].

\section{Employment of graduates of full-time form of study, direction \\ "Construction"in 2017 year.}

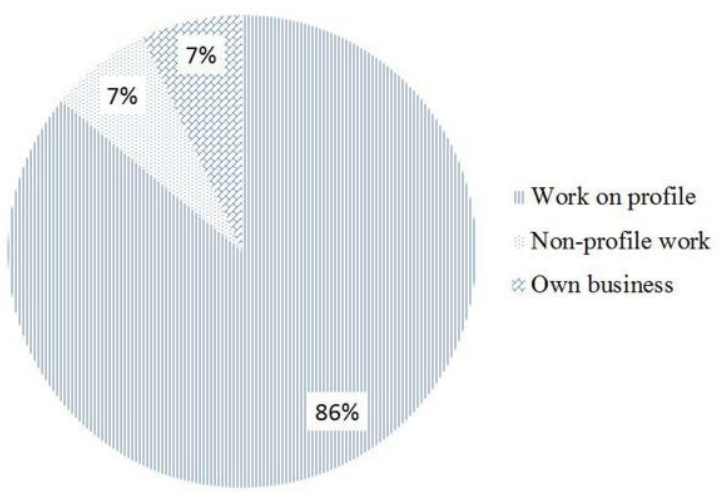

Fig. 2. Diagram of the employment of graduates of the direction «Construction», the profile «Industrial and civil construction» IKBFU in 2017, full-time education. 
As can be seen from the diagram of the employment of graduates of full-time education in the direction «Construction», the profile «Industrial and civil construction» IKBFU in 2017 , employment not by profession is $7 \%$.

Employment of graduates of full-time form of study, direction

"Construction"in 2017 year with regard to conscripts.

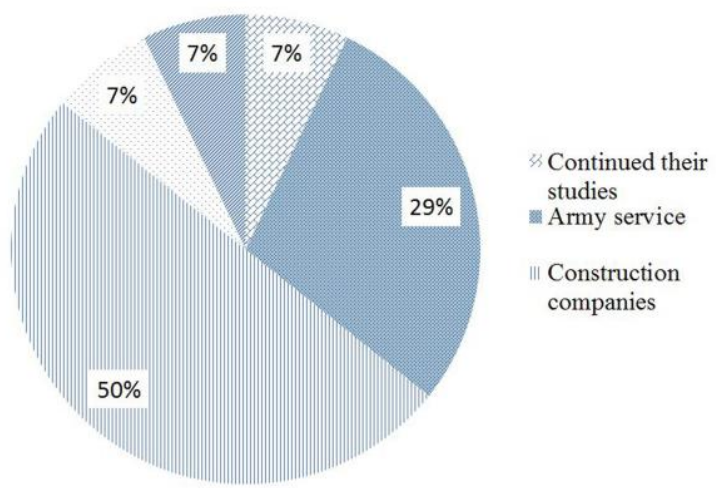

Fig. 3. Employment of graduates of the direction «Construction», the profile «Industrial and civil construction» IKBFU in 2017 with regard to conscripts, full-time education.

According to a survey of graduates of full-time correspondence courses (11 students), not by profession 9\% are employed at the beginning of summer 2018.

\section{Employment of graduates of full-time \& correspondence forms of study, direction "Construction" in 2018 year.}

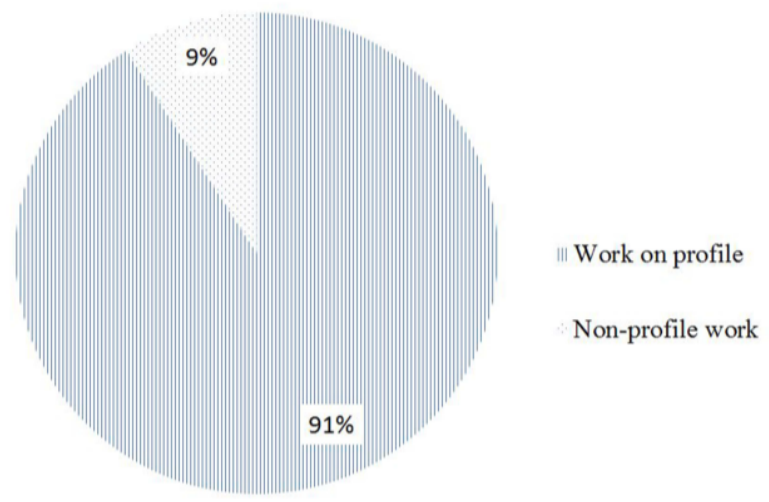

Fig. 4. Diagram of the employment of graduates of the direction «Construction», the profile «Industrial and civil construction» IKBFU in 2018, full-time \& correspondence course of study

Thus, at present more than $90 \%$ of graduates of the direction «Construction» 2017 2018 are employed by profession.

\section{Results and discussion}

In this work, the target audience were graduates of the bachelor's program, the profile «Industrial and civil construction», full-time and part-time correspondence courses. Results 
of monitoring the employment of the first IKBFU graduates of the «Construction» in 2017 2018 showed that more than $90 \%$ are currently employed in the specialty.

According to the survey, the main priorities for employers are graduates with competencies and skills in the production and technical departments of the construction industry:

- Kaliningrad, Russia, CJSC «KMU SZEM», engineer of project technical Department;

- Kerch, Russia, «GlavStroy Engineering», engineer of technical Department;

- Kaliningrad, Russia, LLC «Independent center «Baltexpress»:

- specialist of the Department of construction and technical expertise and integrated design,

- design engineer;

- Kaliningrad, Russia, JSC «Russian Railways», engineer-estimator;

- Kaliningrad, Russia, LLC «Mandrev», engineer of technical Department;

- Kaliningrad, Russia, «AllianceStroiInvest», engineer of project technical Department;

- Yalta, Russia, «Monolith Construction», engineer of project technical Department;

- Kaliningrad, Russia, family building business.

The geography of the employment of graduates and their positions held make it possible to draw a conclusion about the qualitative level of training of our graduates, which guaranteed them the demand on the labor market:

At the same time, the presence of the persistence of graduates in the direction of construction in the Kaliningrad region points out possibility of increasing the effectiveness of the territorial employment policy.

It should be noted that $35.7 \%$ (5 graduates) continued their studies in the magistracy, combining with core activities, including:

- 28.5\% (four graduates) in IKBFU under the program «Modern technologies of designing and calculation of building structures», (contract);

- 7.2\% (one graduate) to St. Petersburg Polytechnic University Peter the Great, Civil Engineering Institute, (budget).

The demand for master's degree training testifies high motivation of graduates to continue their education according basic profile of training.

Modular system of training tool for students in profile disciplines, used in IKBFU, allows successfully master and use theoretical knowledge obtained in practice. When developing a part of the disciplines (modules) relating to the variable part of the bachelor's program, the wishes of employers taken into account or employers are directly involved in these developments. The organization of practices of all types - training, production, prediploma directly at the enterprises of the region, enables employers to select future specialists for their production during the process of training.

The application of trans disciplinary concept in training personnel as a combination of motivation factors in the employment model specific to the labor market allows graduates to be in demand in the regional labor market, which also simplifies the monitoring of labor practices.

Quantitative and qualitative indicators of personnel training serve as an instrument of operational analysis for any industry and allow timely adjustments to the training program.

To identify qualitative indicators of mastering the competence of graduates, a survey questionnaire for managers of construction enterprises in the region has now been developed. Coordination of the educational competencies of the students of the direction 08.03.01 «Construction» with the professional community will allow react to the requests of the industry in a time.

Currently in the region under the higher education program in the direction 08.03.01 «Construction», the profile «Industrial and civil construction» provides training 2 educational institutions: 
- Immanuel Kant Baltic Federal University (IKBFU), (bachelors and masters degrees)

- Kaliningrad State Technical University (bachelors) [11].

However, the establishment of any site is a complex technological process and, specialists of different profiles and with different levels of training participate in its implementation. New specialists will be engaging in this process on various phases of construction. To meet the region need for building in secondary specialized education level personnel the several educational institutions educational institutions provide mid-level training programs, programs for the training of skilled workers, employees, vocational training programs, training programs for occupations, mid-level training programs, such as direction of preparation architecture, construction and operation of buildings and structures, installation, adjustment and operation of electrical equipment of industrial and civil buildings, information systems for urban development, painter, plasterer and other.

Thus, in the Kaliningrad region, 2 higher educational establishments and 8 secondary vocational schools are training personnel for the construction industry [11]. Earlier in the work of the authors it was noted that the total number of graduates with higher education in the direction of «Construction» is not enough to reduce the need for qualified personnel in the region (2014) [12].

According to information posted on the official website of the Ministry of Construction and Housing and Communal Services of the Kaliningrad region, there are more than 100 enterprises in the region specializing in the production of building products (concrete, reinforced concrete products, ceramic bricks, silicate and gas silicate blocks, roofing materials, metal, metal products, sawn timber, paving slabs, composite and PVC materials, inert building materials, plumbing and other materials) [13]. At the same time, abovementioned educational region institutions don't conduct trainings of building materials technology.

According to the monitoring of the needs of personnel in Kaliningrad region construction industry, conducted earlier by the Department of Urban Development, Land Management and Design of the Institute of Nature Management, Territorial Development and Urban Planning of the IKBFU, there was an acute shortage of personnel in the Kaliningrad region directly related to the production of building materials, structures and products (2016) [14].

In connection with the development of additive technologies in construction and the needs for energy-efficient construction, it is necessary to develop training profiles that will be in demand in the foreseeable future, for example, «Designer of 3D printing in construction».

The transition from modular production to the production of a single product using a $3 \mathrm{D}$ printer, the widespread replacement of traditional materials in construction, will lead to the demand for new professional profiles, such as the «System Composite Materials Engineer» [15].

Thus, the analysis of the employment of IKBFU graduates in 2017-2018. directions «Construction» showed that the current priorities of employers determine the variable part of the educational program for the preparation of bachelors, which is changed in the process of development of the construction industry as a whole. Participation of business directly in the process of graduates' preparation allows to minimize risks of individuals' employability.

\section{Conclusions}

The revealed tendencies in the employment of graduates is confirmation of proper orientation towards a modular training system and attraction of representatives of the construction business both to the process of developing academic disciplines and directly to teaching. 
Practice-oriented orientation of the training program allows graduates to be in demand on the labor market.

According to the authors, to meet the needs of the construction industry in the region, taking into account the existing material base of the university, additive technologies development prospects in construction, it is advisable to begin training bachelors and masters in a program directly oriented to the production of building materials, products and structures, including for 3D construction.

\section{References}

1. URL: https://www.kantiana.ru/about/

2. V. Yakovlev, Podgotovka kadrov dlya stroitel'noy otrasli i ZHKKH - URL: http://www.akvobr.ru/podgotovka_kadrov_dla_stroitelnoi_otrasli_i_zhkh.html

3. I. Gar'kin, N. Agafonkina, L. Medvedeva, Opyt realizatsii proyekta po trudoustroystvu studentov «RusWorks», Obr. i nauka v sovr. mire. Innovatsii, 4 (2016)

4. I. Gar'kin, L. Medvedeva, O. Nazarova, Stazhirovka kak faktor budushchego trudoustroystva studentov, Alleya nauki 12(2), p.328-331 (2017)

5. I. Gar'kin, L. Medvedeva, O. Nazarova, Public organizations and university: search forms of interaction, Humanities in the 21st century: scientific problems and searching for effective humanist technologies. 2nd edition: research articles, B\&M Publishing, San Francisco, California. p.62-65 (2016)

6. S. Boldyrev, L. Medvedeva, Yarmarka vakansiy kak instrument sistemy sodeystviya trudoustroystvu molodykh spetsialistov, Obr. i nauka v sovr. mire. Innovatsii, 4, p.7-12 (2016)

7. A. Zhukov, O. Artyukhina, Problema kvalifitsirovannykh kadrov $v$ stroitel'stve, Molodoy uchenyy, 20, p.129-131 (2014)

8. Y. Agafonova, Trudoustroystvo vypusknikov kak odin iz pokazateley effektivnosti raboty vuza na sovremennom etape: analiz, problemy i perspektivy, Kontsept ,10 (2014)

9. Prikaz Minobrnauki Rossii ot 12.03.2015 N 201 «Ob utverzhdenii federal'nogo gosudarstvennogo obrazovatel'nogo standarta vysshego obrazovaniya po napravleniyu podgotovki 08.03.01 Stroitel'stvo (uroven' bakalavriata)» (Zaregistrirovano v Minyuste Rossii 07.04.2015 N 36767)( 2015)

10. Prikaz Ministerstva obrazovaniya i nauki Rossiyskoy Federatsii ot 8.10. 2010 N 1116.

11. Podgotovka kadrov $v$ stroitel'stve. URL: https://minstroy39.ru/building/industry/podgotovka-kadrov-v-stroitelstve

12. L. Shershova, M. Malakhovskaya, Yu. Spirin, Osobennosti regional'nogo rynka truda (na primere stroitel'noy otrasli Kaliningradskoy oblasti) CreateSpace 4900 LaCross Road, North Charleston, SC, USA 29406, 1, p. 258 - 260 (2014).

13. Organizatsii stroyindustrii Kaliningradskoy oblasti. URL: https://minstroy39.ru/building/industry/enterprises.php

14. L. Shershova, S. Shershov, Kadrovy aspekt stroitel'noy otrasli (na primere Kaliningradskoy oblasti), Materialy Tret'yey Vserossiyskoy nauchno-prakticheskoy onlayn-konferentsii s mezhdunarodnym uchastiyem i elementami nauchnoy shkoly dlya molodezhi, Bratsk, Izdatel'stvo BrGU, p.466-473 (2016)

15. Atlas novykh professiy. URL:

http://www.skolkovo.ru/public/media/documents/research/sedec/SKOLKOVO_SEDeC _Atlas.pdf 